\title{
The Relationship Between the Intensity of Using Tik Tok Social Media and Stress Level Among Teenagers in Makassar City During the Pandemic
}

\author{
Nur Syamsu Ismail $^{1 *}$, Andi Tenri Pada Rustham², Arny Ibrahim ${ }^{3}$ \\ ${ }^{1}$ Psychology Department, Hasanuddin University \\ ${ }^{2}$ Psychology Department, Hasanuddin University \\ ${ }^{3}$ Psychology Department, Hasanuddin University \\ *Corresponding author. Email: nursyamsu.ismail@unhas.ac.id
}

\begin{abstract}
The current COVID-19 pandemic requires individuals to keep their distance and maintain their health by doing activities from home, to stay connected to each other, teenagers use various kinds of social media, one of which is tik tok social media. There has been an increase in social media users, especially tik tok, in early 2020 until now. The use of tik tok social media access is carried out excessively for 4-8 hours a day. Excessive use of social media has an impact on stress. For teenagers, this can affect concentration, irritability, and insomnia. Stress that comes from the environment, such as using social media tik tok as a forum for communicating, is considered relevant in creating symptoms of stress manifestations. This study aimed to determine the relationship between the intensity of using tik tok social media access and stress levels in teenagers at Makassar City during the pandemic. This research was quantitative research with a correlational research design. The instruments used in this study were the intensity scale and the PSS-10 (Perceived Stress Scale-10 items). The data analysis used was the Bivariate Pearson Correlation Test. This study indicates a significant positive relationship between the intensity of the use of tik tok access and the stress level of teenagers as user. The coefficient values obtained indicate that the higher the intensity of using tik tok social media, the higher the stress level for active tik tok users.
\end{abstract}

Keywords: Intensity of Social Media, Stress, Teenagers

\section{INTRODUCTION}

The pandemic occurred because of the global epidemic caused by the COVID-19 virus. The current pandemic requires individuals to keep their distance and maintain their health by doing activities from home to break the chain of virus spread. One of the aspects affected by the pandemic is education, especially youth, to fulfill their developmental tasks, so teenagers build a relationship during the pandemic by using the internet, namely social media, to stay connected with peers. Teenagers use various kinds of social media, one of which is Tik Tok social media. There has been an increase in the use of social media during the pandemic, especially tik tok social media in early 2020 until now, where teenagers access tik tok social media for 4 to 8 hours a day. Of course, excessive use of social media impacts teenagers, just like stress. For teenagers, this can affect concentration, irritability, and insomnia. Stress that comes from the environment, such as using social media tik tok as a forum for communication, is considered relevant in creating symptoms of stress manifestations in teenagers.

Santrock also said that during adolescence, the changes that occur are accompanied by transformations in relationships and finding identity, while teenagers can develop socio-emotional problems, such as juvenile delinquency, stress, and even depression [1]. When teenagers look for identity, they will try to build relationships with peers. This relationship is built using technology, namely the internet, especially social media. The benefits obtained when using the internet in sufficient time as a forum for communication include making it easier for individuals to form a common group (interests and motivations) so that individuals can join in a community, make it easier to access information, and help users share content with others. Available 
applications [2]. However, the use of mobile phones, especially in accessing excessive social media, can cause addiction and psychological and physical disorders such as found that most or as many as $51.4 \%$ of teenagers were addicted to social media. Low, and half of the adolescents or as much as $48.6 \%$ are addicted to high levels of social media [3].

Meanwhile, research found that adolescents were in the moderate addiction category with a percentage of $64.8 \%$, adolescents in the low category with a percentage of $20.4 \%$, and adolescents with a high level of $13.6 \%$, which means half of teens are addicted to social media [4]. Excessive intensity can also occur because of an interest in something based on quality, namely as a form and attention of adolescents and emotional feelings that involve appreciation and interest in these activities [5]. Revealed that tik tok has a negative impact if accessed for a long time, namely exposure to pornographic content, boredom, to loneliness, stress, and fear of being left behind, making teenagers more active in accessing tik tok [6]. Revealed that teenagers who are active in using social media can feel a change in sleep patterns, causing insomnia, difficulty concentrating, mood swings, sensitivity, and difficulty interacting. The insomnia phenomenon among adolescents is caused by stress, chronic disorders, poor diet, lack of exercise, and an unfavorable environment [7].

When individuals experience stress, individuals tend to become more irritable and impatient in dealing with various situations. Stress can occur because of the stressor, which is the cause of stress. This happens because a cognitive process does not follow the emergence of negative thoughts that result in stress [8]. Based on the exposure results, there have been several indications of the emergence of sources of stress in adolescents caused by excessive media use. Research revealed that late teens are the most active social media users and are mostly at risk of experiencing mental health problems with a high percentage [9]. In addition, quoted through the Jawapos.com news page, it states that as many as $60 \%$ of teenagers experience stress due to excessive use of social media. Research conducted found that the influence of social media can have an impact on stress, this occurs because individuals are worried about their privacy and are concerned about the number of people who like posts and comments on their social media [10]. This anxiety is what causes stress, anxiety itself is a fundamental mental health problem.

\section{METHOD}

This study uses quantitative research using the correlational method, emphasizing the analysis of quantitative data (numbers) collected through measurement procedures and processed using statistical analysis methods. Respondents in this study were active teenagers using Tik Tok social media aged from 13 to 20 years who lived in Makassar City. The data collection technique used is the intensity of social media access and the PSS-10 scale or Perceived Stress Scale. The number of respondents in this study was 168 respondents.

This correlation research data analysis uses Pearson's product-moment correlation analysis technique, which measures the associative hypothesis of two variables if the data is interval or ratio with a symmetrical relationship direction. Research data can have a relationship or correlation if $\mathrm{p}<5 \%$, and if $\mathrm{p}>$ $5 \%$, then the hypothesis is rejected.

\section{RESULT AND DISCUSSION}

The profile of the respondents and hypothesis testing result are shown in the table below.

Table 1. Respondent profile

\begin{tabular}{cccccc}
\hline & \multicolumn{2}{c}{ Age } & \multicolumn{2}{c}{ Intensity } \\
\hline $13-16$ & $17-20$ & Male & Female & 4 Hours & $5-8$ Hours \\
\hline 35 & 133 & 44 & 124 & 133 & 35 \\
respondents & respondents & respondents & respondents & respondents & respondents \\
\hline
\end{tabular}

Table 2. Hypothesis Testing

\begin{tabular}{lccc} 
& $\mathrm{N}$ & Person Correlation & Sig. (2-tailed) \\
\hline Intensity of Social Media & 168 & 0.367 & 0.000 \\
\hline
\end{tabular}


Display equations should be flush left and numbered consecutively, with equation numbers in parentheses and flush right. First, use the equation editor to create the equation. Then, select the equation, and set the "Equation" Style. Press the tab key and type the equation number in parentheses. Based on the correlation test results carried out using the Pearson correlation hypothesis test, the Pearson correlation value is 0.367 , which indicates that the value is included in the moderate relationship criteria based on the De Vaus correlation coefficient criteria [11].

The results of data analysis conducted in this study indicate that the intensity of using Tik Tok social media access and stress levels have a significant relationship. This is in line with the stages of adolescent developmental tasks, namely adolescent socioemotional, biological, and cognitive development, where adolescents experience many significant changes in their lives to build relationships and socialize with their peers [1]. The study results also show that the level of intensity of adolescents in accessing social media is in the moderate category overall. This is in accordance with the research that found that most teenagers $(51.4 \%)$ experienced lowlevel social media addiction, and almost half of the adolescents $(48.6 \%)$ experienced high social media addiction levels [3]. The respondent's stress level is in the medium category, leading to high.

This means that most of the respondents experience high stress due to the intensive use of social media for a long period. According to the theory, stress arises due to a transactional stimulus, meaning that the stressor appears to be a stimulus to stress in adolescents $[12,13]$. The more stressors that occur, the more triggers appear and increase the level of stress felt by adolescents. The results of this study are also in line, which found that adolescents experience stress due to the use of social media because it is influenced by various factors, one of which is the high use of mobile phones or mobile phones [14]. The results of data analysis in this study indicate that the intensity of social media use with stress levels has a significant positive relationship. This means that the higher the intensity of adolescents in accessing tik tok social media, the higher the stress level experienced by adolescents. According to Lazarus and Cohen [15] suggest that one of the stress factors that arise due to the environment, namely background stressors, which are daily problems in life and the social environment, and these stressors have a small impact on individuals but if they occur continuously it will generate negative stress. Examples include having responsibilities, feeling lonely, arguing, peer conflicts, poor interpersonal relationships, social environment (cell phone use), and disputes with family.

Based on this, it can be seen that the social environment is correlated with stress. Research conducted [16] states that the cause of the high intensity of social media use among adolescents is based on fear of missing out on information, connecting with peers, and priorities in updating social media. Then, teenagers who are active in using social media more intensely can feel changes such as sleep patterns, headaches, insomnia, difficulty in interacting, mood swings, and stress manifestations that can arise in adolescents [16].

According [1] to the stage of adolescent development, especially the stage of social development, adolescents experience many changes in their lives, especially in terms of socializing with their peers. Adolescence is also inseparable from stress, which is identified with storm and stress or a turbulent period characterized by conflict and mood swings. The existence of rapid changes, difficulties in socializing, conflicts with peers, disputes with parents, and media use are indications of the emergence of stress in adolescents. When associated with the help of social media, the use of tik tok social media for some teenagers is a stressor, both individuals posting on social media or viewing content on social media.

The response that appears in each individual is undoubtedly different, and these negative feelings will then form coping so that teenagers can make decisions to continue accessing the tik tok application, reduce interaction with the application, or choose not to access the tik tok application. Research [6] suggests that teenagers who are intense in accessing social media applications are prone to psychological disorders, such as hearing loss, causing obesity, insomnia, impaired muscle development at preschool age, and stress.

\section{CONCLUSION}

Our study concludes that there is a significant positive correlation between the intensity of using social media tik tok and the level of stress of teenagers in Makassar City during the pandemic. Worthy to note, the correlation effect is on a moderate level. This means that other factors need to be explored that affect the stress level among teenagers. 


\section{REFERENCES}

[1] Santrock, J. W. Life-Span Development (Perkembangan Masa Hidup 13 ed. Penerjemah: Widyasinta, B. Jakarta: Erlangga, 2011.

[2] Amedie, J. The Impact of Social-Media on Society. Santa Clara University: Final Journal Paper, 2015.

[3] Aprilia, R., Sriati, A., \& Hendrawati, S. Tingkat kecanduan media sosial pada remaja. $J N C$, Vol. 3, No. 1. 2020.

[4] Wulandari, R. \& Netrawati, N. Analisis tingkat kecanduan media sosial pada remaja. Jurnal Riset Tindakan Indonesia, Vol. 5, No. 2, 2020, 41-46.

[5] Ajzen, Icek. Attitudes, Personality, and Behavior. New York: Open University Press. 1991.

[6] Damayanti, T. \& Gemiharto, I. Kajian dampak negatif aplikasi berbagi video bagi anakanak di bawah umur di Indonesia. Communication, Vol. 10, No. 1, 2019.

[7] Arifianti, D. A. Hubungan Penggunaan Media Sosial dan Tingkat Stres dengan Insomnia Remaja di SMA Negeri 9 Surabaya. Fakultas Keperawatan. Universitas Airlangga. 2019.

[8] Sarafino, E. P. Health Psychology: Biopsychological Interactions. New York: John Wiley \& Sons. 2008.

[9] The Hearty Soul. Using media social is causing anxiety, stress and depression. 2016. Retrieved from http://theheartysoul.com/mental-healthrisksof-social-media/.

[10] Bhat, S. Effects of social media on mental health. The International Journal of Indian Psychology. Vol. 4, No. 3, 2016.

[11] De Vaus, D. A. Surveys in Social Reseacrh, $5^{\text {th }}$ ed. New South Wales: Allen \& Unwin. 2014.

[12] Lyon, B. L. Stress, coping, and health. In Rice, H. V. (Eds.) Handbook of stress, coping and health: Implications for nursing research, theory, and practice, USA: Sage Publication, Inc, 2012. pp.3-23.

[13] Bartlett, D. Stress: Perspectives and processes. Philadelphia, USA: Open University Press. 1998.
[14] Simangunsong, S. \& Sawitri, D. R. Hubungan stres dan kecanduan smartphone pada siswa kelas X SMA Negeri 5 Surakarta. Jurnal Empati, Vol. 6, No. 4, 2017, pp. 52-66

[15] Candra, W. I. Psikologi: Landasan Keilmuwan Praktik Keperawatan Jiwa. Yogyakarta: Penerbit Andi. 2017.

[16] Syamsoedin, W. K. P., Bidjuni, H., \& Wowling, F. Hubungan durasi penggunaan media sosial dengan kejadian insomnia pada remaja di sma negeri 9 manado. E-journal Keperawatan (E$K p)$, Vol. 3, No. 1-10, 2015. 